\title{
Strategic decision for the external technological innovation acquisition mode selection by using an integration of AHP and GRA methods: A case study on a Thai new technology-based firm
}

\author{
Detcharat Sumrit ${ }^{1}$, Asst. Prof. Dr. Pongpun Anuntavoranich ${ }^{2}$, \\ Assoc. Prof. Dr. Pakpachong Vadhanasindhu ${ }^{3}$ \\ ${ }^{1,2}$ Technopreneurship and Innovation Management Program, Graduate School, \\ Chulalongkorn University, Bangkok, Thailand. \\ ${ }^{3}$ Faculty of Commerce and Accounting, Chulalongkorn University, Bangkok, Thailand.
}

\begin{abstract}
The selection of the most appropriated external technological acquisition mode for a specific technological innovation is one of the important strategic decision-makings. To solve the complicated decision making problem, this study aims (i) to identify the multi-attribute criteria which influenced the selection of the external technological innovation acquisition mode and (ii) to illustrate the comprehensive proposed model by applying Multi-Criteria Decision Making (MCDM) approach, which was combined of Analytic hierarchy process (AHP) and Grey Relational Analysis (GRA) methods. The result can provide the prioritization of the relative important weight of criteria and the final ranking of alternative. This study is expected to effectively assist the managements or the decision-makers to choose the best appropriated alternatives which matched with their business objectives. A study case for the Thai technology-based firm was also applied in this article.
\end{abstract}

Keywords- Analytic hierarchy process, External technological innovation acquisition mode, Grey relational analysis, Multi-criteria decision-making method.

\section{Introduction}

For the forthcoming of Asean Econmic Community (AEC) in 2015, main changes brought to ASEAN countries including Thailand are free flow of labors, goods \& services, capitals, and investment. These will inevitably cause the severe competitions among region and global as well as face the uncertainty of environmental conditions. Regarding to AEC, the managements may have some key concerns such as (i) the ability to improve its core competency including technological innovation development which can be obtained from internal or external sources, (ii) the improvement of the manufacturing and operational process in order to rapidly response to the market's needs, (iii) the business strategy adjustment to sustain the competitive advantage. Under the uncertainties of technology changes and global circumstances, one of the important solutions is technology innovation, which firms need to diversify business for business growth or survival [1]. Despite technology has become increasingly complicated and played more crucial roles in the recent decades; firms cannot develop all technologies they needed [2], [3]. Thus, Technology sourcing strategy and its effective implementation and formulation are considerably used to develop new technology capability for external and inhouse R\&D activities [1], [4], [5]. Generally, firms can apply a mixture of strategies to acquire technology innovation capability from endogenous and exogenous sources. Following to this, the strategic decision-making on technology sourcing is highly important as it is believed to improve the firms' innovative capabilities in an enhancement of the competitive advantage. Belderbos, et al. [6] defined technology sourcing is a method which firms can get the related R\&D technology from in-house R\&D and external technology sourcing e.g. suppliers, competitors, and customers.

When a firm will conduct a decision-making, all available technology acquisition modes are provided to the firm as the choices of decision-making. It is necessary that a firm should select the best suitable mode for the demanded technology acquisition [7]. In addition, the way to acquire the needed technology is one of the crucial strategic decision-making in generating the technological strategy. Jones [8] supported that technology acquisition is one of the important methods to improve firms' technology and accumulate their main resources. Technology acquisition can be also obtained by the internal development, or the cooperation from other institutions or buying the definite technology [9]. However, under the time limitation, the restricted capital of investment, the narrow core competency, the quick respond to market's needs, it was envisaged that the internal R\&D activity had been no longer a primary resource for a technological acquisition [10].

A review of the related literatures found that firms must also pursue the external technological sourcing in order to sustain firms' competitive advantages under major reasons e.g. (i) focus on core competencies [11], (ii) reduce the cost of technological development [12], [13], [14], (iii) build an expertise of new technology, develop the process to the existing staffs, and speedy in the product launch [11], [12], (iv) make the resources 
flexibility [12], [13], and (v) minimize the business risk [12]. For the Thai new technology-based firms, they are currently the powerful drivers to accelerate a Thailand's economic growth. These firms provide a higher remarkable contribution to country such as GDP growth, higher employment opportunities, increasing the communities' incomes and develop social surroundings. Given the weakness of in-house R\&D activities as above mentioned, the Thai new technology-based firms also realize the importance of the external technological innovation sourcing in order to fasten their technological innovation improvement and to maintain their competitive advantages aligning with the recent coming of AEC in 2015.

From the literature reviews, it was observed that a few researches conducted the external technological innovation acquisition modes by applying MCDM method to select a firm's appropriated choice. Therefore, to fulfill this gap, the challenging objectives of this study are (i) to describe the rationale criteria and alternatives of the external technological innovation acquisition modes via a proposed model, consisting of a comprehensive set of criteria. This was to understand which the specific technological acquisition selection mode should be required by a firm and (ii to illustrate the systematic analytical methods by using a combination of AHP and GRA in order to provide the best ranking as a solution for the managements. This study contributes to effectively assist the decision makers to ease their complicated decision-making on a definite selection mode.

The remainder of this paper was organized as follow; Section 2 presented the literature review of external technological innovation sourcing, and the theoretical methods of AHP and GRA. Section 3 explained the research methodology, including AHP and GRA. Section 4 described a model implementation on the Thai new technology-based firms as a case study. Finally, Section 5 ended with the conclusion.

\subsection{The External Technological Innovation Sourcing}

\section{Literature Review}

The concept of the external technological innovation sourcing has been increasingly obtained more attentions from the managements because of (i) an intense competition and the technological complexity, causing firms need to pace in the technological knowledge outside their boundaries [15] and (ii) a higher importance of external technology linkage that firms can often obtained the technology from its external sources [16]. Technology, nowadays, becomes much more complicated and difficult for firms to independently develop the required technology [17], resulting the firms can become a good partner or an acquirer of external technology. According to the preceding literatures, the external sources utilization in the development of technological capabilities has been steadily rising. External technology source is an important resource that a firm must definitely acquire in order to achieve business's goal [19]. During the past few decades, firms have dramatically employed the complementary resources from external as it is easy for a simple firm to sustain its existing competitive advantages, and at the same time, it can create new competitiveness [20]. The external technology sourcing can also contribute the desired knowledge in an exchange to the supportive institutions such as the accounting consultant firms, the universities and the governmental agencies [21].

A number of previous researchers studied on the different modes of collaboration depend on their specific objectives. For instance, Santoro and McGill [22] discriminated the five external technology modes in a consideration of the market transaction and the integrated solution, i.e. a licensing, a cross-licensing, a bilateral alliance, a minority equity alliance and equity joint ventures. While Villalonga and McGahan [23] investigated how firms selected among modes of the alliances, the acquisitions, the divestitures in boundary-expanding and boundary-contracting. However, most common terms for the external technological sourcing modes were joint ventures, strategic alliances and other types in inter-organizational collaboration [24]. Since there are too many alternatives of technology collaboration, in summary, our analysis focused on five major selection modes of external acquisition strategies, which were also often adapted in Thailand i.e. (1) licensing, (2) joint venture, (3) R\&D contract, (4) joint R\&D and (5) private label, as shown in Table 1.

Table 1: Five major external technological innovation acquisition modes

\begin{tabular}{|l|l|c|}
\hline Selection Mode & \multicolumn{1}{|c|}{ Description } & Authors \\
\hline Licensing & $\begin{array}{l}\text { A firm acquires a license for a specific technology and accesses to the associated } \\
\text { know-how }\end{array}$ & {$[25],[26],[27]$} \\
\hline Joint Venture & $\begin{array}{l}\text { A firm establishes a formal joint venture with the equity involvement and a third } \\
\text { corporation is created with a definite objective of technological innovation }\end{array}$ & {$[28],[25]$} \\
\hline R\&D contract & $\begin{array}{l}\text { A firm agrees to fund the R\&D cost for a research institute or university or small } \\
\text { innovative firm for a definite technology }\end{array}$ & {$[25]$} \\
\hline Joint R\&D & $\begin{array}{l}\text { A firm agrees with others to jointly carry out the R\&D for a definite technology } \\
\text { (or technological discipline) without the equity involvement }\end{array}$ & {$[25]$} \\
\hline Private Label & $\begin{array}{l}\text { A firm acquires the capability by buying another firm's core products and } \\
\text { assembly them to sell }\end{array}$ & {$[29]$} \\
\hline
\end{tabular}




\begin{tabular}{|c|c|c|}
\hline Evaluation Criteria & Description & Authors \\
\hline $\begin{array}{l}\text { Fit with business strategy } \\
\left(C_{1}\right)\end{array}$ & $\begin{array}{l}\text { The selected external technological innovation acquisition mode fits } \\
\text { with the firm's business strategy. }\end{array}$ & {$[30],[5],[31]$} \\
\hline $\begin{array}{l}\text { Fit with technology strategy } \\
\left(\mathrm{C}_{2}\right)\end{array}$ & $\begin{array}{l}\text { The selected external technological innovation acquisition mode fits } \\
\text { with the firm's technology strategy. }\end{array}$ & [9] [5] \\
\hline $\begin{array}{l}\text { Prior collaboration history } \\
\text { with target }\left(\mathrm{C}_{3}\right)\end{array}$ & $\begin{array}{l}\text { The prior cooperation enhances the firm's willingness to enter a } \\
\text { relationship that is less reversible and that involves a higher level of }\end{array}$ & $\begin{array}{c}32],[33], \\
{[34]}\end{array}$ \\
\hline $\begin{array}{l}\text { Internal resistance to } \\
\text { external technological }\end{array}$ & $\begin{array}{l}\text { An organization perceives the external technological innovation as a } \\
\text { threat which may lead the responses in a resistance. }\end{array}$ & $\begin{array}{c}{[35],[36],} \\
{[37]}\end{array}$ \\
\hline $\begin{array}{l}\text { Accelerate technology } \\
\text { learning \& Absorptive } \\
\text { canacitv }\left(\mathrm{C}_{5}\right)\end{array}$ & $\begin{array}{l}\text { The selected external technological innovation acquisition mode } \\
\text { accelerates the firm's technology learning and harnesses the firm's } \\
\text { absorntive canacitv. }\end{array}$ & [9], [38] \\
\hline Total of acquisition cost & All acquisition cost involved in the external technological & [3], [9], [5] \\
\hline $\begin{array}{l}\text { Seed for future technology } \\
\text { development }\left(C_{7}\right)\end{array}$ & $\begin{array}{l}\text { The selected external technological innovation acquisition mode } \\
\text { leads a firm to seed for the future technology development. }\end{array}$ & [9], [39] \\
\hline $\begin{array}{l}\text { Asset specialization } \\
\text { requirement }\left(\mathrm{C}_{8}\right)\end{array}$ & $\begin{array}{l}\text { The external technological innovation collaboration's activities } \\
\text { require the highly specialized assets which are dedicated to the }\end{array}$ & [25] \\
\hline $\begin{array}{l}\text { Degree of control over } \\
\text { activities and results }\left(\mathrm{C}_{9}\right)\end{array}$ & $\begin{array}{l}\text { Firms have the possibilities and the rights to determine the activities } \\
\text { and results in which the output is achieved and the resources are }\end{array}$ & [25] \\
\hline $\begin{array}{l}\text { Technological innovation } \\
\text { distance }\left(\mathrm{C}_{10}\right)\end{array}$ & $\begin{array}{l}\text { The overlap of the technological knowledge base between the } \\
\text { investing company and the external sources. }\end{array}$ & $\begin{array}{l}40],[41], \\
{[33],[24]}\end{array}$ \\
\hline Level of reversibility $\left(\mathrm{C}_{11}\right)$ & $\begin{array}{l}\text { The characteristics of the relationship of the external collaboration } \\
\text { can be modified or easily to be abandoned. }\end{array}$ & [25] \\
\hline $\begin{array}{l}\text { Technology modularity } \\
\left(\mathrm{C}_{12}\right)\end{array}$ & $\begin{array}{l}\text { The degree to which a change in the design of one element requiring } \\
\text { a compensation of the design changes in other elements. }\end{array}$ & {$[25],[42]$} \\
\hline $\begin{array}{l}\text { Hasten product market entry } \\
\left(\mathrm{C}_{13}\right)\end{array}$ & $\begin{array}{l}\text { The selected external technological innovation acquisition mode } \\
\text { leads firm to expedite a new product introduction into the market. }\end{array}$ & [43], [44] \\
\hline $\begin{array}{l}\text { Appropriability mechanism } \\
\left(\mathrm{C}_{14}\right)\end{array}$ & $\begin{array}{l}\text { The degree to which a firm can capture the rents from its innovation } \\
\text { and the strength of mechanism to protect the knowledge and } \\
\text { innovation from imitators. }\end{array}$ & $\begin{array}{l}{[3],[9],[45],} \\
{[5]}\end{array}$ \\
\hline Level of risk $\left(\mathrm{C}_{15}\right)$ & $\begin{array}{l}\text { The uncertainty level of both technology and commerce may be } \\
\text { significantly varied to the activities and the potential results of the }\end{array}$ & [9], [39] \\
\hline Partner uncertainty $\left(\mathrm{C}_{16}\right)$ & $\begin{array}{l}\text { The situation of an information asymmetry that the investing firm has } \\
\text { not yet accessed to all the relevant information in order to make a } \\
\text { decision in the technology collaboration process with a partner. }\end{array}$ & {$[46],[47]$} \\
\hline $\begin{array}{l}\text { Availability and quality of } \\
\text { external resources }\left(\mathrm{C}_{17}\right)\end{array}$ & $\begin{array}{l}\text { The availability and the quality of the external resources can easily } \\
\text { lead a definite decision-making for the technology collaboration. }\end{array}$ & [9], [48], [5] \\
\hline
\end{tabular}

\subsection{Analytical Hierarchy Process (AHP)}

AHP is a multiple-criteria decision-making method to solve the problems in the uncertainty conditions and to evaluate several criteria in the decision making procedure [49]. The MCDM model aims to assist a decision maker with an accurate reference and reduce the risky decision-making. By decomposing the decision problems into a hierarchy of more comprehensible sub-criteria, each criterion can be independently assessed. The elements of the hierarchy can connect to any aspect of the decision problems, and it can be utilized in the various fields [50]. The calculation of AHP is stepped as follows [51], [52]:

Step 1) Conduct the pair-wise comparison matrix A by adopting the ratio scale, shown in Table 3.

Table 3: The ratio scale of the intensity importance level

\begin{tabular}{|c|l|l|}
\hline $\begin{array}{c}\text { Intensity of } \\
\text { Importance }\end{array}$ & \multicolumn{1}{|c|}{ Definition } & \multicolumn{1}{|c|}{ Description } \\
\hline 1 & Equal important & Two factors equally contribute to the objective \\
\hline 3 & Somewhat more important & Experience and judgment slightly favor one over the other \\
\hline 5 & More important & Experience and judgment strongly favor one over the other \\
\hline 7 & Much more important & $\begin{array}{l}\text { Experience and judgment very strongly favor one over the } \\
\text { other. Its importance is demonstrated in practice. }\end{array}$ \\
\hline 9 & Absolutely more important & $\begin{array}{l}\text { The evidence favoring one over the other is of the highest } \\
\text { possible validity }\end{array}$ \\
\hline $2,4,6,8$ & Intermediate values & Need the compromise \\
\hline
\end{tabular}

Source: Saaty [51] 
Step 2) Let $a_{i j}$ represents a quantified judgment on a pair of element $C_{i}, C_{j}$. While $C_{1}, C_{2}, \ldots$, and $C_{n}$ denote the series of elements. It results an n-by-n matrix A, as follows:

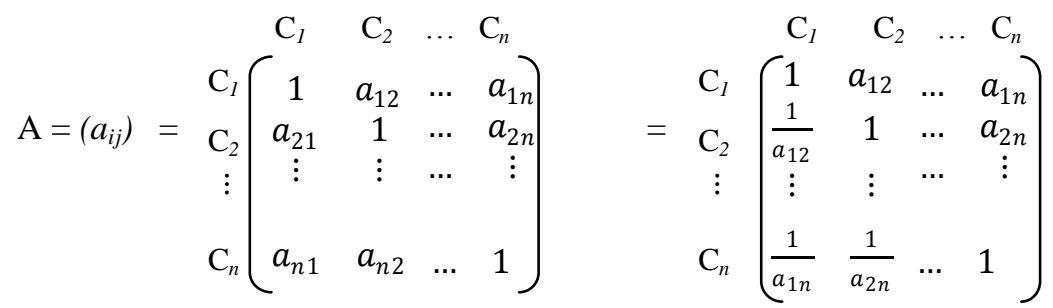

where $a_{i j}=1$ and $a_{i j}=\frac{1}{a_{i j}}, i, j=1,2, \ldots, n$.

In matrix $\mathrm{A}$, the problem is constructed to assign the $\mathrm{n}$ elements $\left(C_{1}, C_{2}, \ldots, C_{n}\right)$, a set of numerical weight $\left(W_{l}, W_{2}, \ldots, W_{n}\right)$ which reflect the recorded judgments. If $\mathrm{A}$ is a consistency matrix, then the relations between weights $W_{i}$ and judgments $a_{i j}$ are given by $\frac{W_{j}}{W_{i}}=a_{i j}$ (for $\left.\mathrm{i}, \mathrm{j}=1,2, \ldots, n\right)$. The largest Eigen-value $\left(\lambda_{\max }\right)$ is computed as below [51];

$$
\lambda_{\max }=\sum_{j=1}^{n} a_{i j} \frac{W_{j}}{W_{i}}
$$

If $\mathrm{A}$ is a consistency matrix, then the Eigen-vector $\mathrm{X}$ can be computed by

$$
\left(A-\lambda_{\max } I\right) X \quad=\quad 0
$$

Consistency index $(C I)$ and Random index $(R I)$ are applied to verify Consistency ratio $(C R)$ as follows:

$$
\begin{aligned}
& \mathrm{CI}=\frac{\lambda_{\max }-n}{n-1} \\
& C R=\frac{C I}{R I}
\end{aligned}
$$

RI, as the average consistency of square matrices, is derived from the various $n$ orders, filling with the random entries [53]. The average consistency values of these matrices are determined as shown in Table 4, [54]. If $C R<0.10$, the consistence of the pair-wise comparison matrix is acceptable; otherwise new comparison matrix is requested until $C R<0.1$.

Table 4: RI values

\begin{tabular}{c|ccccccc}
\hline $\mathrm{n}$ & 2 & 3 & 4 & 5 & 6 & 7 & 8 \\
\hline $\mathrm{RI}$ & 0 & 0.52 & 0.90 & 1.12 & 1.24 & 1.32 & 1.41 \\
\hline
\end{tabular}

\subsection{Grey Relational Analysis (GRA)}

GRA is determined as a system with the discrete data and the partial information in order to solve the problems. The typical feature of GRA is to simply manage the smaller data and enable to achieve the good results. GRA is performed by data assigning in the regular place with a proper process [55], [56], [57]. The procedure of the GRA calculation is as follows [58], [59].

Step 1) Illustrate the reference sequence as

$$
\mathrm{X}_{0}=\left(\mathrm{X}_{01}, \mathrm{X}_{02}, \ldots, \mathrm{X}_{0 n}\right)
$$

Step 2) Express the $m$ sequences to be shown as

$$
\mathrm{X}_{i}=\left(\mathrm{X}_{i 1}, \mathrm{X}_{i 2}, \ldots, \mathrm{X}_{i n}\right), \quad i=1,2, \ldots, m
$$

Step 3) Gather the score data by $k$ experts and calculate the Geometric mean (GM) as below;

$$
\mathrm{GM}=\left(\pi_{i=1}^{k} X_{i n}\right)^{\frac{1}{k}}, \quad k=\text { numbers of experts }
$$

Step 4) Normalize the sequences to assure all of them are in the same order, and the normalized sequences can be denoted as

$$
x_{i}^{*}=\left(x_{i 1}^{*}, x_{i 2}^{*}, \ldots, x_{i n}^{*}\right), \quad i=1,2, \ldots, m
$$

For upper-bound (larger-the-better) $x_{i}$ indices, the normalized data can be formulated by

$$
x_{i}^{*}=\frac{X_{i j}}{X_{i \max }}, \quad i=1,2, \ldots, m, \quad j=1,2, \ldots, n
$$


For lower-bound (smaller-the-better) $x_{i}$ indices, the normalized data can be obtained by

$$
x_{i}^{*}=\frac{X_{i \min }}{X_{i j}}, \quad i=1,2, \ldots, m, \quad j=1,2, \ldots, n
$$

where $x_{\text {imax }}$ and $x_{\text {imin }}$ are the maximum and minimum values of the $i^{\text {th }}$ row, respectively.

Step 5) Denote the grey relational coefficient $(\xi)$ between the compared sequence, $x_{i}$, and the reference sequence, $x_{0}$, for the $\mathrm{j}^{\text {th }}$ factor $(\mathrm{j}=1,2 \ldots \mathrm{n})$, as follows:

$$
\xi_{i j}=\frac{\min _{i}\left(\min _{i}\left|x_{0 j}-x_{i j}^{*}\right|\right)+\rho \max _{i}\left(\max _{j}\left|x_{0 j}-x_{i j}^{*}\right|\right)}{\left|x_{0 j}-x_{i j}^{*}\right|+\rho \max _{i}\left(\max _{j}\left|x_{0 j}-x_{i j}^{*}\right|\right)}
$$

where $\mathrm{x}_{\mathrm{ij}}^{*}$ is the grey relational coefficient between the $i^{\text {th }}$ index of the $j^{\text {th }}$ alternative to be evaluated and $i^{\text {th }}$ element of the reference (or optimal) sequence;

where $\xi_{i j} \in[0,1], x_{i j}^{*}$ is the value of factor $j$ of grid $i$, the distinguish coefficients $(\rho) \in[0,1]$, and typically $\rho=$ 0.5 .

Step 6) Represent the aggregated evaluation model by Grey relational Grade $(\Gamma)$, as follows:

$$
\Gamma_{\mathrm{i}}=\sum_{j=1}^{n} w_{j} \xi_{i j}
$$

where $\Gamma_{\mathrm{i}}$ is the integrated evaluation value of grid $i, w_{j}$ is the weight for factor $j$ of grid $i$, and $\Gamma_{\mathrm{i}} \in[0,1]$.

\section{Research Methodology}

This study established a framework procedure comprising of four main steps of the selection of an external technological innovation acquisition, shown in Fig.1. Firstly, the 17 multi-criteria were identified by the extraction from the several literatures, as displayed in Fig. 2. The second step was to construct a criteria selection model, illustrated in Fig.2. The validity of criteria characteristic and model were also confirmed by the six experienced experts ( 2 from academic and 4 from industrial firms). Thirdly, after obtaining the valid model, a group of the eleven managerial staffs of a selected Thai new technology-based firm as a case study provided a consensus opinion on all relative weight pair-wise comparison of criteria. The criteria prioritization was thereafter calculated by AHP through Expert Choice version 11.0 software, shown in Fig.3. The last step, GRA was applied to calculate the final ranking of all alternatives, providing the best selection to the decision makers.

$\begin{gathered}\text { Step 1) } \\ \begin{array}{c}\text { Review literatures and } \\ \text { extract the related multi- } \\ \text { criteria attribution. }\end{array}\end{gathered} \mid \begin{gathered}\text { Step 2) } \\ \text { Construct the proposed model } \\ \text { and confirmed the model } \\ \text { validity by six experts }\end{gathered}$
$\begin{gathered}\text { Determine the relative } \\ \text { weight of criteria by } \\ \text { applying AHP method }\end{gathered}$

igure1: Framework procedure for the selection of an external technological innovation acquisition

External Technological Innovation Acquisition Mode Selection

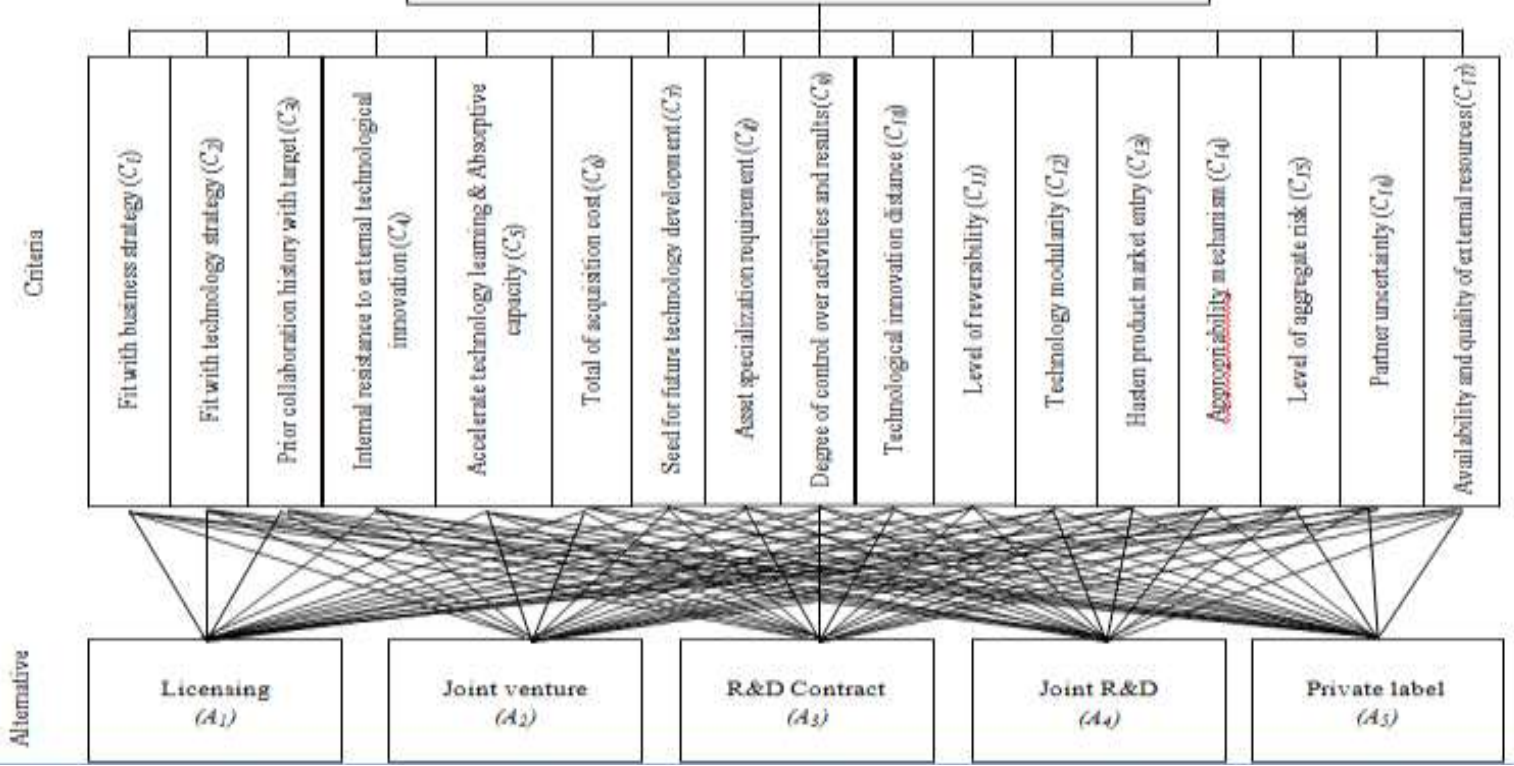

Figure 2: The selection model of external technological innovation acquisition 


\section{Case implementation}

This study conducted an example of a famous new technology-based firm particular to Thai automotive parts industry. This company planned to improve its existing technological innovation capability by acquiring a new technological innovation from the external acquisition modes in order to enhance its competitive advantage and to deal with a higher severe competition according to the AEC's commencement in 2015. Its management and a decision-making team deliberately considered to select only one from the five most appropriated modes of the external technological innovation acquisition. Such alternatives are (i) licensing, (ii) joint venture, (iii) R\&D contract, (iv) joint R\&D and (iv) private label. The steps of the selection process were shown as following.

\subsection{The determination of the weight of criteria by using AHP method}

After obtaining the identification of the seventeen criteria and the validated selection model from Fig.2, the 11 firm's managerial staffs provided a pair-wise comparison of the criteria and mutually agreed all of the relative importance weight of criteria. The intensity of importance scale was adopted with a respect to Saaty's ratio scale in Table 3. The Expert Choice version 11.0 software was thereafter applied to calculate the relative importance weight. In Fig. 3, the weight prioritization was revealed that the top-five important weights of criteria were $\mathrm{C}_{5}, \mathrm{C}_{1}, \mathrm{C}_{2}, \mathrm{C}_{7}$, and $\mathrm{C}_{13}$, with the score of $0.161,0.145,0.114,0.105$, and 0.076 , respectively.

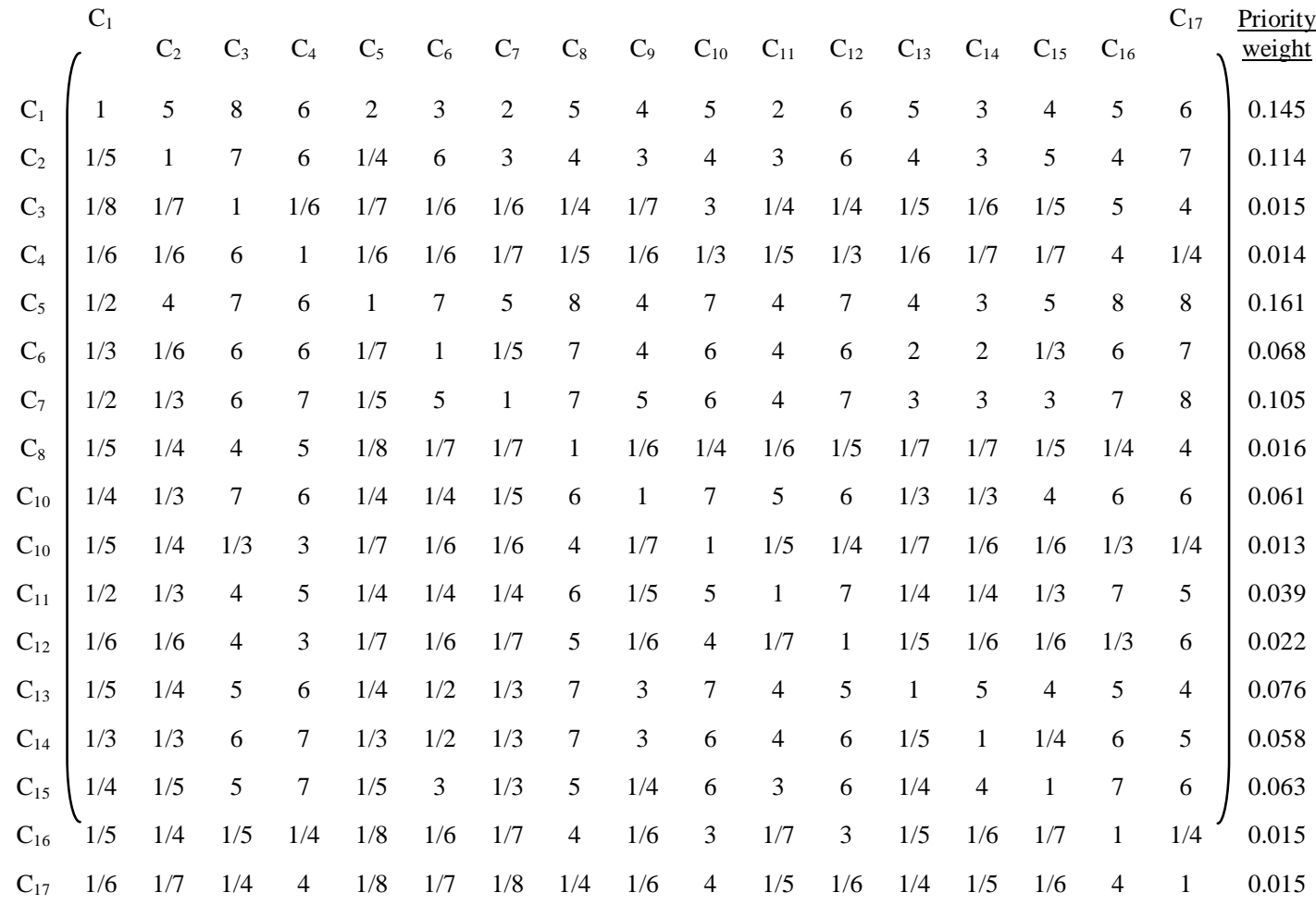

Figure 3: The relative weights of criteria for pair-wise comparison by AHP method

4.2 The utilization of GRA method for ranking and selecting a final alternative

After obtaining the relative weights of the seventeen criteria by AHP method from the previous section, the same group of experts rated each alternative against each criterion. Thereafter the GRA approach was performed to compute the weight selection of each alternative. The characteristic of all criteria were qualitative, except for $\mathrm{C}_{6}$ (Total of the acquisition cost) was quantitative, which the acquisition cost was estimated depending on each alternative $\left(\mathrm{A}_{1}\right.$ to $\mathrm{A}_{5}$ ) i.e. USD5.5m, USD9m, USD4.5m, USD7.5m, and USD10.5m, respectively. In term of the beneficial characteristic of criteria, 9 of 17 were upper-bound (larger-the-better), i.e. $\mathrm{C}_{1}, \mathrm{C}_{2}, \mathrm{C}_{3}, \mathrm{C}_{5}, \mathrm{C}_{7}, \mathrm{C}_{9}, \mathrm{C}_{11}, \mathrm{C}_{14}$, and $\mathrm{C}_{17}$. The remaining of 8 criteria were lower-bound types (smaller-the-better) i.e. $\mathrm{C}_{4}, \mathrm{C}_{6}, \mathrm{C}_{8}, \mathrm{C}_{10}, \mathrm{C}_{12}, \mathrm{C}_{13}, \mathrm{C}_{15}, \mathrm{C}_{16}$. The measurement scale for the operation in GRA method was illustrated in Table 5. 
Strategic decision for the external technological innovation acquisition mode selection by using an

Table 5: The rating score measurement for the operation in GRA method

\begin{tabular}{|c|c|c|c|c|c|c|c|c|c|c|c|c|c|c|c|c|c|}
\hline & $C_{I}$ & $C_{2}$ & $C_{3}$ & $C_{4}$ & $C_{5}$ & $C_{6}$ & $C_{7}$ & $C_{8}$ & $C_{9}$ & $C_{10}$ & $C_{11}$ & $C_{12}$ & $C_{13}$ & $C_{14}$ & $C_{15}$ & $C_{16}$ & $C_{17}$ \\
\hline $\begin{array}{c}\text { Qualitative } \\
\text { (rating score } \\
\text { measurement 1 to 5)* }\end{array}$ & $\checkmark$ & $\checkmark$ & $\checkmark$ & $\checkmark$ & $\checkmark$ & & $\checkmark$ & $\checkmark$ & $\checkmark$ & $\checkmark$ & $\checkmark$ & $\checkmark$ & $\checkmark$ & $\checkmark$ & $\checkmark$ & $\checkmark$ & $\checkmark$ \\
\hline Quantitative & & & & & & $\checkmark$ & & & & & & & & & & & \\
\hline $\begin{array}{c}\text { Upper-bound } \\
\text { (Larger-the-better) }\end{array}$ & $\checkmark$ & $\checkmark$ & $\checkmark$ & & $\checkmark$ & & $\checkmark$ & & $\checkmark$ & & $\checkmark$ & & & $\checkmark$ & & & $\checkmark$ \\
\hline $\begin{array}{c}\text { Lower-bound } \\
\text { (Smaller-the-better) }\end{array}$ & & & & $\checkmark$ & & $\checkmark$ & & $\checkmark$ & & $\checkmark$ & & $\checkmark$ & $\checkmark$ & & $\checkmark$ & $\checkmark$ & \\
\hline
\end{tabular}

*Remark: 1 (very poor) to 5 (very good)

After acquiring the scores collection assigned by each expert, the average scores of geometric mean was computed by using above formula (8), as resulted in Table 6. Data was then normalized by formula (10) and (11), as displayed in Table 7. The calculation of Grey relational coefficient $\left(\xi_{i j}\right)$ and Grey relational Grade $\left(\Gamma_{\mathrm{i}}\right)$ were formulated by the equation (12) to (13), as summarized in Table 8 and Table 9, respectively.

The final results of the ranking alternatives were summarized in Table 10, which was found that the Joint venture $\left(A_{2}\right)$ was the most appropriated alternative of the external technological innovation acquisition mode based on the highest score of grey relational grade $\left(\Gamma_{2}\right)$ at 0.707 , followed by Joint $R \& D\left(A_{4}, \Gamma_{4}=0.618\right)$, Private Label $\left(A_{5}, \Gamma_{5}=0.604\right), R \& D$ Contract $\left(A_{3}, \Gamma_{3}=0.517\right)$ and Licensing $\left(A_{1}, \Gamma_{1}=0.506\right)$, respectively. In Fig. 4, the graph represented the comparisons of the grey relational grade weights among all criteria in conjunction with each alternative, at the distinguish coefficients $(\rho)=0.5$. The sensitivity of two scenarios by using the distinguish coefficient $(\rho)=0.3$ and 0.7 were conducted, as shown in Table 11-12, and Fig.5-6, respectively. The result indicated that the alternative 'Joint venture' $\left(\mathrm{A}_{2}\right)$ was still the best selection for this company, and the alternative ranking was still unchanged, given the values of $\Gamma_{i}$ i.e. $A_{2}>A_{4}>A_{5}>A_{3}>A_{1}$.

Table 6: The decision-making matrix (Geometric mean)

\begin{tabular}{|c|c|c|c|c|c|c|c|c|c|c|c|c|c|c|c|c|c|}
\hline & $C_{l}$ & $C_{2}$ & $C_{B}$ & $C_{4}$ & $C_{s}$ & $C_{6}$ & $C_{7}$ & $C_{\hat{z}}$ & $C_{\theta}$ & $C_{10}$ & $C_{n}$ & $C_{h 2}$ & $C_{l s}$ & $C_{l i}$ & $C_{l s}$ & $C_{l \sigma}$ & $C_{l 7}$ \\
\hline Licensing $\left(A_{1}\right)$ & 2.66 & 3.09 & 3.05 & 2.95 & 2.59 & 5.5 & 1.95 & 2.26 & 2.15 & 1.83 & 2.26 & 2.32 & 2.76 & 2.83 & 2.32 & 2.59 & 3.33 \\
\hline Joint Venture $\left(A_{2}\right)^{-}$ & $3.70^{\circ}$ & 3.678 & 1.66 & 2.26 & 3.28 & $9^{-}$ & 3.60 & 4.17 & $3.51^{-}$ & 2.15 & 1.46 & 2.73 & 1.61 & 2.44 & 2.86 & 2.27 & 3.90 \\
\hline R\&D Contract $\left(A_{-}\right)^{-}$ & $2.9 \mathrm{I}^{-}$ & $3.01^{-}$ & 2.74 & 2.32 & 2.32 & 4.5 & 3.11 & 3.90 & 3.08 & 3.90 & 2.58 & 3.33 & 3.11 & 1.88 & 2.32 & 3.11 & $-3.33^{-}$ \\
\hline Joint $R \& D\left(A_{4}\right)$ & 3.01 & 3.14 & 2.26 & 3.76 & 2.62 & $7.5^{-}$ & 3.08 & $2.13^{-}$ & $3.90^{-}$ & -3.08 & 3.90 & 2.89 & 3.08 & 3.76 & '.88 & 3.53 & 2.94 \\
\hline Private Label $\left(\mathrm{A}_{5}\right)^{--}$ & 1.72 & 1.29 & $1.87^{-}$ & 2.89 & 3.90 & 10.76 & 3.90 & 2.89 & 3.08 & 2.08 & 2.89 & 2.08 & 2.08 & 3.08 & 2.89 & 2.13 & $2.72^{-}$ \\
\hline
\end{tabular}

Table 7: Summary of the normalization data

\begin{tabular}{|c|c|c|c|c|c|c|c|c|c|c|c|c|c|c|c|c|c|}
\hline & $C_{l}$ & $C_{2}$ & $C_{s}$ & $C_{\epsilon}$ & $C_{\xi}$ & $C_{6}$ & $C_{7}$ & $C_{s}$ & $C_{\phi}$ & $C_{10}$ & $C_{n}$ & $C_{12}$ & $C_{l s}$ & $C_{h t}$ & $C_{l s}$ & $C_{l \sigma}$ & $C_{17}$ \\
\hline Licensing $\left(A_{1}\right)$ & 0.47 & 0.76 & 1.00 & 0.54 & 0.17 & 0.84 & 0.00 & 0.94 & 0.00 & 1.00 & 0.33 & 0.81 & 0.24 & 0.51 & 0.57 & 0.67 & 0.52 \\
\hline Joint Venture $\left(\mathrm{A}_{2}\right)^{-}$ & $1.00^{\circ}$ & 1.00 & 0.00 & 1.00 & 0.61 & 0.28 & 0.85 & 0.00 & 0.78 & 0.84 & 0.00 & 0.48 & $1.00^{\circ}$ & 0.30 & 0.03 & 0.90 & 1.00 \\
\hline R\&D Contract $\left(\mathrm{A}_{3}^{-}\right)^{--}$ & 0.60 & 0.72 & 0.78 & 0.96 & 0.00 & 1.00 & 0.60 & 0.13 & 0.53 & 0.00 & 0.46 & $0.00^{-}$ & 0.00 & 0.00 & $0.57^{-}$ & $0.30^{\circ}$ & 0.52 \\
\hline Joint R\&D $\left(A_{4}\right)$ & 0.65 & 0.78 & 0.43 & 0.00 & 0.19 & 0.52 & 0.58 & 1.00 & 1.00 & $0.40^{-}$ & 1.00 & 0.35 & 0.02 & 1.00 & 1.00 & 0.00 & 0.19 \\
\hline Private Label $\left(\mathrm{A}_{s}\right)$ & 0.00 & 0.00 & 0.15 & 0.58 & 1.00 & 0.00 & 1.00 & 0.63 & 0.53 & 0.88 & 0.59 & $1.00^{\circ}$ & 0.69 & 0.64 & $0.00^{\circ}$ & $1.00^{\circ}$ & 0.00 \\
\hline
\end{tabular}

\begin{tabular}{|c|c|c|c|c|c|c|c|c|c|c|c|c|c|c|c|c|c|}
\hline & & & & & & & & & & & & & & & & & \\
\hline & $C_{l}$ & $C_{2}$ & $C_{3}$ & $c_{4}$ & $C_{s}$ & $C_{6}$ & 4 & 4 & $c$ & $c_{10}$ & $c_{11}$ & $C_{12}$ & $C_{13}$ & $C_{1 / 4}$ & $C_{l s}$ & $C_{16}$ & $C_{17}$ \\
\hline Licensing $\left(A_{1}\right)$ & 0.49 & 0.67 & 1.00 & 0.52 & 0.38 & 0.76 & 0.33 & 0.89 & 0.33 & 1.00 & 0.43 & 0.72 & 0.39 & 0.50 & 0.54 & 0.60 & 0.51 \\
\hline Joint Venture $\left(A_{2}\right)^{-}$ & 1.00 & $1.00^{-}$ & 0.33 & $1.00^{\circ}$ & 0.56 & $0.41^{-}$ & $0.77^{-}$ & $0.33^{-}$ & 0.69 & 0.76 & 0.33 & $0.49^{-}$ & $1.00^{\circ}$ & $0.42^{-}$ & 0.34 & 0.83 & $1.00^{\circ}$ \\
\hline R\&D Contract $\left(A_{g}\right)$ & 0.56 & 0.64 & $0.69^{-}$ & 0.93 & $0.33^{-}$ & 1.00 & $0.55^{-}$ & 0.37 & 0.52 & 0.33 & 0.48 & 0.33 & $0.33^{-}$ & $0.33^{-}$ & 0.54 & 0.42 & 0.51 \\
\hline Joint R\&D $\left(\mathrm{A}_{4}\right)$ & 0.59 & $0.69^{-1}$ & $0.47^{-}$ & 0.33 & 0.38 & $0.5 \mathrm{r}^{-}$ & 0.54 & $1.00^{-}$ & 1.00 & $0.45^{-1}$ & 1.00 & 0.44 & 0.34 & $1.00^{-}$ & $1.00^{\circ}$ & 0.33 & 0.38 \\
\hline Private Label $\left(A_{s}\right)$ & 0.33 & $0.33^{-1}$ & 0.37 & 0.54 & $1.00^{-}$ & 0.33 & $1.00^{\circ}$ & 0.57 & 0.52 & $0.81^{-1}$ & 0.55 & $1.00^{-}$ & 0.62 & 0.58 & 0.33 & 1.00 & 0.33 \\
\hline
\end{tabular}

Table 9: Summary of Grey relation Grade $\left(\Gamma_{i}\right)$

\begin{tabular}{|c|c|c|c|c|c|c|c|c|c|c|c|c|c|c|c|c|c|c|}
\hline \multirow{3}{*}{$\begin{array}{c}\text { AHP relative } \\
\text { weight }\end{array}$} & 0.15 & 0.11 & 002 & 001 & 016 & 0,07 & 0.12 & 002 & 0,06 & 001 & 0,04 & 002 & 008 & 00 & 00 & 90 & 7 & \\
\hline & & & & & & & & & & & & & & & & & & \\
\hline & $C_{l}$ & $C_{2}$ & $C_{s}$ & $C_{4}$ & $C_{s}$ & $C_{6}$ & $C_{7}$ & $C_{\delta}$ & $C_{\ell}$ & $C_{10}$ & $C_{l l}$ & $C_{l 2}$ & $C_{l s}$ & $C_{l i}$ & $C_{l s}$ & $C_{16}$ & $C_{l n}$ & wi \\
\hline Licensing $\left(A_{1}\right)$ & 0.07 & 0.08 & 0.02 & 0.01 & 0.06 & 0.05 & 0.04 & 0.01 & 0.02 & 0.01 & 0.02 & 0.02 & 0.03 & 0.03 & 0.03 & 0.01 & 0.01 & 0.506 \\
\hline Joint Venture $\left(A_{2}\right)$ & 0.15 & $0.11^{-}$ & 0.01 & 0.01 & $0.09^{-}$ & 0.03 & 0.08 & $0.01^{-}$ & 0.04 & 0.01 & 0.01 & $0.0 \mathrm{I}^{-}$ & 0.08 & 0.02 & 0.02 & 0.01 & 0.02 & 0.707 \\
\hline $\begin{array}{c}\text { R\&D Contract } \\
\left(A_{3}\right)\end{array}$ & 0.08 & 0.07 & $0.01^{-}$ & $0.01^{-}$ & 0.05 & 0.07 & 0.06 & 0.01 & 0.03 & $8.01^{-}$ & 0.02 & $0.01^{-}$ & $0.03^{-}$ & 0.02 & 0.03 & $0.01^{-}$ & 0.01 & 0.517 \\
\hline Joint R\&D $\left(A_{4}\right)$ & 0.09 & 0.08 & 0.01 & 0.01 & 0.06 & 0.04 & 0.06 & 0.02 & 0.06 & 0.01 & 0.04 & 0.01 & $0.03^{-}$ & $0.06^{-}$ & 0.06 & 0.01 & 0.01 & 0.618 \\
\hline Private Label $\left(\mathrm{A}_{5}\right)$ & 0.05 & $6.04^{-1}$ & $0.01^{-}$ & 0.01 & 0.16 & 0.02 & 0.11 & 0.01 & 0.03 & 0.01 & 0.02 & 0.02 & 0.05 & 0.03 & 0.02 & 0.02 & 0.01 & 0.604 \\
\hline
\end{tabular}




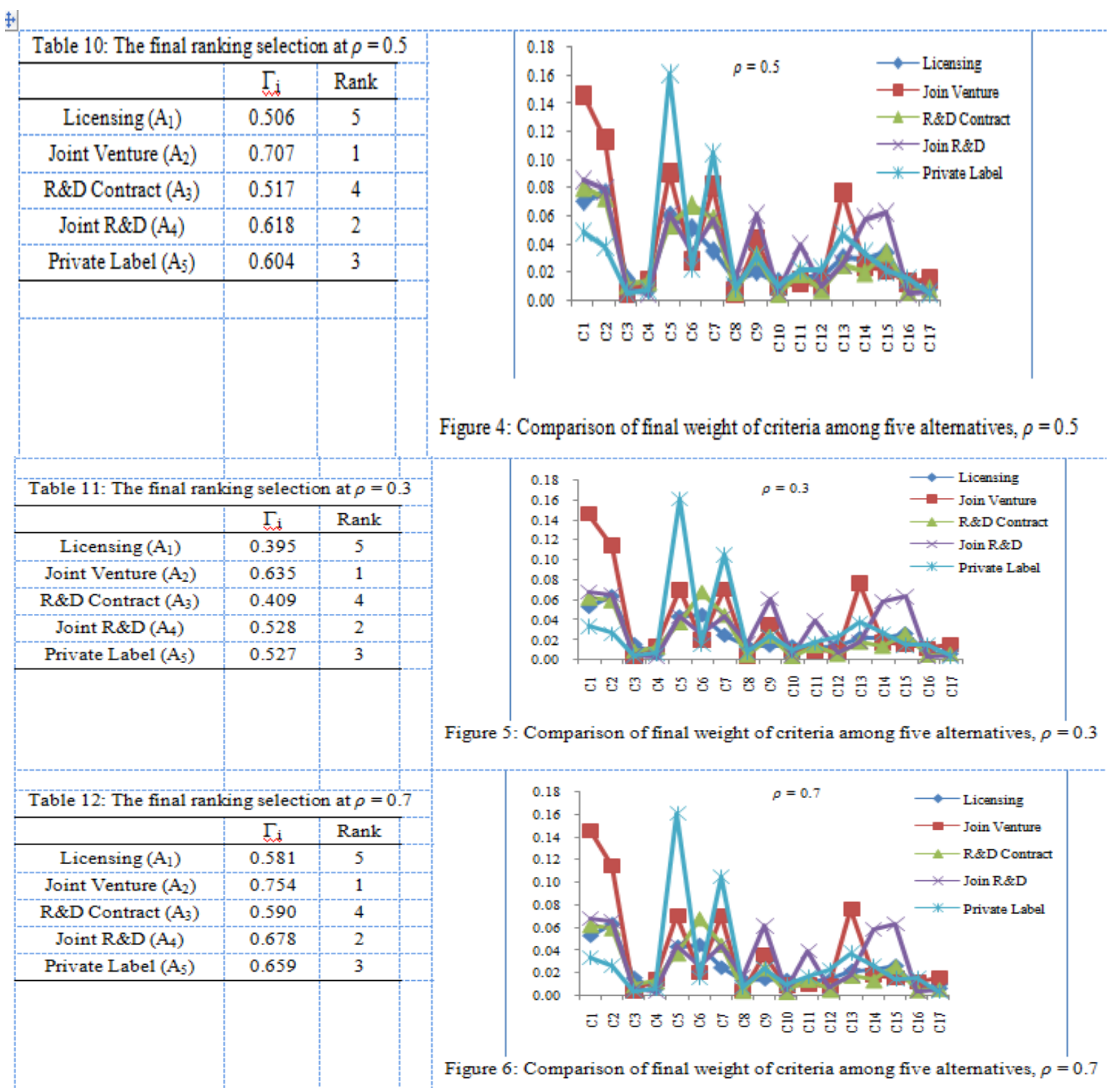

\section{Conclusion}

The selection of external technological innovation acquisition was considered as a highly complicated strategic decision problem when firms had to choose the specific technological collaboration mode. To acquire the appropriated alternative, the model development of a decision-making process was thus crucial to support the managements' decision making. This research proposed an effective multi-criteria decision model by using two techniques i.e. (i) AHP approach is to calculate and prioritize the relative importance weight of evaluation criteria and (ii) GRA approach is to provide the most appropriated alternative by the weighted ranking. The illustration of this proposed model was presented in a case study of Thai new technological-based firm, particularly in automotive parts industry. In this case, the conclusion was that "Joint venture" was the most significant alternative influencing the selection of the external technological innovation acquisition mode. For other industries, the management or the experts in such specific industries can apply this systematic approach with some adjustments in the alternative modes and the weight of evaluation criteria. Moreover, the future research may require other hybrid MCDM methods in a consideration of the cause and effect relationship among evaluation criteria.

\section{References}

[1] H. Zhao, X. Tong, P.K. Wong, and J. Zhu, Types of technology sourcing and innovative capability: An exploratory study of Singapore manufacturing firms, Journal of High Technology Management Research, 16, 2005, 209-224.

[2] M. Radnor, Technological acquisition strategies and a processes: A reconsideration of the market versus buy decision, International Journal of Technology Management, 6, 1991, 113-135. 
[3] D. H. Cho, and P.I. Yu, Influential factors in the choice of technology acquisition mode: An empirical analysis of small and medium size firms in Korean telecommunication industry, Technovation 20(12), 2000, 691-704.

[4] E. Auster, The inter-organizational environment: network theory, tools and applications, In F. Williams, and D. Gibson (Eds.), Technology Transfer: A Communications Perspective. Sage, (Newbury Park, CA, 1990), 63-89.

[5] H. Lee, S. Lee, and Y. Park, Selection of technology acquisition mode using the analytic network process, Mathematical and Computer Modelling, 29, 2009, 1274-1282.

[6] R. Belderbos, M. Carree, B. Lokshin, Cooperative R\&D and firm performance, Research Policy, 33, $2004,1477-1492$.

[7] K. Clarke, D. Ford, M. Saren, and R. Thomas, Technology strategy in UK firms, Technology Analysis and Strategic Management, 7, 1995, 169-190.

[8] G. K. Jones, A. Lanctot, and H. J. Teegen, Determinants and performance impacts of external technology acquisition, Journal of Business Venturing, 16(3), 2000, 255-283.

[9] V. Chiesa, R\&D Strategy and Organization: Managing Technical Change in Dynamic Contexts (Imperial College Press, London, 2001).

[10] R. Coombs, A reflection on the major themes of the 1997 R\&D management conference, R\&D Management, $28,1998,213-215$.

[11] Y. Zhao and R.J. Calantone, The trend toward outsourcing in new product development: case studies in six firms. International Journal of Innovation Management, 7(1), 2003, 51-66.

[12] B.S. Piachaud, Outsourcing in the pharmaceutical manufacturing process: an examination of the CRO experience, Technovation, 22(2), 2002, 81-90.

[13] S. Kumar, and T. Snavely, Outsourcing and strategic alliances for product development: a case of Banta Digital Group. Technovation, 24(12), 2004, 1001-1010.

[14] M. K. Bolton, Imitation versus innovation: Lessons to be learned from the Japanese. Organizational Dynamics, 21 , 1993 , $30-45$.

[15] C. W. Hsu, Formation of industrial innovation mechanisms through the research institute, Technovation, 25, $2005,1317-1329$.

[16] J. Niosi, Introduction: the internationalization of industrial R\&D, from technology transfer to the learning organization, Research Policy, 28, 1999, 107-117.

[17] M. Radnor, Technological acquisition strategies and a process: A reconsideration of the market versus buy decision, International Journal of Technology Management, 6, 1991, 113-135.

[18] D. Chartterji, Accessing external sources of technology. Research-Technology Management (March-April), 1996, 48-56.

[19] F.H. Rhode, IS/IT outsourcing practices of small-and medium-sized manufacturers. International Journal of Accounting Information System, 5, 2004, 429-451.

[20] J.S. Harrison, M.A. Hitt, R.E. Joskisson, and R.D. Ireland, Resource complementarity in business combinations: extending the logic to organizational alliance. Journal of Management, 27, 2001, 679-690.

[21] D. Hislop, The client role in consultancy relations during the appropriation of technological innovations. Research Policy, 31, 2002, 657-671.

[22] M.D. Santoro, and J.P. McGill, The effect of uncertainty and asset co-specialization on governance in biotechnology alliances. Strategic Management Journal, 26, 2005, 1261-1269.

[23] B. Villalonga, and A.M. Mcgahan, The choice among acquisitions, alliances, and divestitures. Strategic Management Journal, 26, 2005, 1183-1208.

[24] V.V.D. Vrande, W. Vanhaverbeke, G. Duysters, External technology sourcing: The effect of uncertainty on governance mode choice. Journal of Business Venturing, 24, 2009, 62-80.

[25] V. Chiesa, R. Manzini, and F. Tecilla, Selecting sourcing strategies for technological innovation: an empirical case study, International Journal of Operations \& Production Management, 20(9), 2000, 1017 - 1037.

[26] T. Yoshikawa, Technology development and acquisition strategy. International Journal of Technology Management, 25(6-7), 2003, 666-674.

[27] S. Kurokawa, Make-or-buy decisions in R\&D: small technology based firms in the United States and Japan, IEEE Transactions on Engineering Management, 44(2), 1997, 124-134.

[28] J. Hagedoorn, Organizational modes of inter-firm co-operation and technology transfer, Technovation, 10(1), 1990, 17-30.

[29] A. Afuah, Innovation Management (New York, N.Y.: Oxford University Press, Inc., 2003).

[30] B.B. Allred, and K.S. Swan, Contextual influences on international subsidiaries' product technology strategy, Journal of International Management, 10 (2), 2004, 259-286.

[31] V.K. Narayanan, Y. Yang, and S.A. Zahra, Corporate venturing and value creation: a review and proposed framework, Research Policy, 38( 1), 2009, 58-76.

[32] J. Howells, A. James, and K. Malik, The Sourcing of Technological knowledge: distributed innovation processes and dynamic change, R\&D Management, 33(4), 2003, 395-409.

[33] V.V.D. Vrande, C. Lemmens and W. Vanhaverbeke, Choosing governance modes for external technology sourcing. R\&D Management, 36(3), 2006, 347-363.

[34] P. Kale, and M. Zollo, Understanding partnering process and outcomes: the contribution of evolutionary theory, from Oded S. and Jeffery R. edit, Handbook of strategic alliance, 5 (Sage Press, 2006).

[35] R. Katz, and T.J. Allen, Investigating the Not-Invented-Here (NIH) Syndrome: A Look at the Performance, Tenure and Communication Patterns of 50 R\&D Project Groups, R\&D Management, 12, 1982, 7-19.

[36] R. Veugelers and B. Cassiman, Make and buy in innovation strategies: evidence from Belgian manufacturing firms, Research Policy, 28, 1999, 63-80.

[37] U. Lichtenthaler and H. Ernst, Attitudes to Externally Organizing Knowledge Management Tasks: A Review, Reconsideration and Extension of the NIH Syndrome, $R \& D$ Management, 36(4), 2006, 367-386.

[38] I. Hipkin, Determining technology strategy in developing countries, Omega 32(3), 2004, $245-260$.

[39] S. Ghazinoory, and M. Farazkish, A model of technology strategy development for Iranian nano-composite companies Technological and Economic Development of Economy, 16(1), 2010, 25-42.

[40] A.B Jaffe, Technological opportunity and spillovers of R \& D: evidence from firms' patents, profits, and market value. The American Economic Review, 76 (5), 1986, 984-1001.

[41] R.C. Sampson, Organizational choice in R\&D alliances: knowledge based and transaction cost perspective, Managerial and Decision Economics, 25, 2004, 421-436.

[42] C.H., Loch, A. De Meyer, and M.T. Pich, Managing the unknown: a new approach to managing high uncertainty and risk in projects, (Wiley and Sons, New York, 2006). 
[43] B.S. Piachaud, Outsourcing in the pharmaceutical manufacturing process: an examination of the CRO experience, Technovation 22 (2), 2002, 81-90.

[44] Y. A. Huang, H.J. Chung, and C. Lin, R\&D sourcing strategies: Determinants and consequences, Technovation, 29, 2009, 155-169.

[45] J. Hagedoorn, D. Cloodt, and H. Kranenburg, Intellectual property rights and the governance of international R\&D partnerships, Journal of International Business Studies, 36, 2005, 175-186.

[46] J.J. Reuer, and M.P. Koza, Asymmetric information and joint venture performance: Theory and evidence for domestic and international joint ventures, Strategic Management Journal, 21, 2000, 81-88.

[47] W. Vanhaverbeke, G. Duysters, G., and N. Noorderhaven, External technology sourcing through alliances or acquisitions: An analysis of the application-specific integrated circuits industry, Organization Science, 13, 2002, 714-733.

[48] M. Hemmert, The influence of institutional factors on the technology acquisition performance of high-tech firms: Survey results from Germany and Japan, Research Policy, 33 (6-7), 2004, 1019-1039.

[49] T.L. Saaty, How to make a decision: the analytic hierarchy process, European Journal of Operation Research, 40, 1971, 9-10.

[50] T.L. Saaty, The Analytic Hierarchy Process (McGraw-Hilll, NY, 1980).

[51] T.L. Saaty, How to make a decision: the analytic hierarchy process, European Journal of Operation Research, 48(1), 1990, 9-26.

[52] C.R. Wu, C.W. Chang, and C.C. Liao, Group decision making apply to select collaborative technology of software contractor, Proceeding International Conference on Business and Information, Kuala Lumpur, Malaysia, 2009.

[53] T.L. Saaty, A scaling method for priorities in hierarchical structures, Journal of Mathematical Psychology, 15, 1977, $231-281$.

[54] T.L. Saaty, and L.G. Vargas, Prediction, Projection and Forecasting (Kluwer Academic Publishes, Dordrecht, 1991).

[55] P. Li, T.C. Tan, and J. Y. Lee, Grey Relational Analysis of Amine Inhibition of Mild Steel Corrosion in Acids, Corrosion, 53, 1997, 186-194.

[56] J.L. Deng, Essential Topics on Grey System: Theory and Applications (Wuhan: Huanzhong University of Science and Technology Press, 1987).

[57] G. Sasikumar, V. Selladurai, and A. Sivasangari, Development of a Supplier Selection System by Combining Analytic Hierarchy Process and Grey Relational Analysis: An Automobile Industry Case Study, The Iefai University Journal of Supply Chain Management, 5(4), 2008, 82-94.

[58] S. Cheng, and R. Wang, Analyzing hazard potential of typhoon damage by applying grey analytic hierarchy process, Natural Hazards, 33, 2004, 77-103.

[59] F. Yang, G. M. Zeng, C. Du, L. Tang, J. Zhou, and Z. Li, Integrated Geographic Information Systems-Based Suitability Evaluation of Urban Land Expansion: A Combination of Analytic Hierarchy Process and Grey Relational Analysis, Environmental Engineering Science, 26(6), 2009, 1025-1032. 